\title{
STATUS CZYNNEGO PODATNIKA VAT A PRAWO DO ODLICZENIA PODATKU NALICZONEGO
}

\begin{abstract}
Artykuł przedstawia zagadnienie, które ciągle wywołuje wiele sporów na linii organy podatkowe - podatnik, a więc prawa do odliczenia podatku naliczonego w sytuacji braku rejestracji dla potrzeb podatku VAT. W artykule dokonano scharakteryzowania definicji podatnika VAT czynnego zawartego w ustawie o VAT. Ponadto omówiono terminy i tryb rejestracji, a także aktualizacji danych zawartych w rejestrze VAT. Poruszona została również kwestia wykreśleń z rejestru podatników VAT czynnych w podziale na powody wykreślenia. Zagadnienie będące tematem artykułu zostało zaprezentowane dwutorowo. Jeden z rozdziałów został poświęcony analizie sytuacji podmiotu, który nabywa towary bądź usługi dokumentowane fakturami VAT nie będąc zarejestrowanym podatnikiem VAT czynnym, a w kolejnym omówiono tę problematykę od strony kontrahentów podmiotu niezarejestrowanego. Celem artykułu jest przedstawienie zagadnienia w ujęciu kompleksowym, tj. zarówno w kontekście ustawodawstwa i orzecznictwa unijnego, jak i krajowego, a także praktyki organów podatkowych. Analizując sytuację kontrahentów nabywających towary i usługi od podmiotu niezarejestrowanego szczególną uwagę zwrócono na zagadnienia , dobrej wiary” i „,należytej staranności" nieodłącznie związanymi z prawem do odliczenia podatku VAT w takiej sytuacji. Problematyka ta została zaprezentowana w kontekście ustawodawstwa krajowego (w szczególności ustawy o VAT), praktyki organów podatkowych, a także orzecznictwa Trybunału Sprawiedliwości i sądów krajowych. Zasadniczą konkluzją wynikającą z artykułu jest potrzeba każdorazowego badania przez organy podatkowe i sądownictwo dobrej wiary podatnika, oraz dochowania przez niego zasad należytej staranności. Reasumując - sprowadza się to do badania, czy podatnik w konkretnej sprawie działał w sposób rzetelny i uczciwy. Jeżeli tak - zasadne jest przyznanie mu prawa do odliczenia podatku naliczonego, nawet przy pewnych uchybieniach natury formalnej czy proceduralnej (w tym braku rejestracji dla potrzeb podatku VAT).
\end{abstract}

Słowa kluczowe: podatek VAT, rejestracja VAT, Trybunał Sprawiedliwości, sądownictwo krajowe, organy podatkowe, podatek naliczony.

\section{WPROWADZENIE}

Przedmiotem artykułu jest zagadnienie rejestracji dla potrzeb podatku VAT w kontekście prawa do odliczenia podatku naliczonego. Problem ten dotyczy zarówno podmiotu niezarejestrowanego, jak i jego kontrahentów.

\footnotetext{
${ }^{1}$ Mgr Jerzy Pukała, Uniwersytet Ekonomiczny w Krakowie, ul. Rakowicka 27, 31-510 Kraków; e-mail: jerpuk@wp.pl.

Jerzy Pukała, MA, Faculty of Finance and Law, Cracow University of Economics, Rakowicka 27, 31-510 Kraków; e-mail: jerpuk@wp.pl.
} 
W ustawie z dnia 11 marca 2014 roku o podatku od towarów i usług ${ }^{2}$ znajdujemy generalną zasadę dotyczącą prawa do skorzystania z podatku naliczonego. Art. 86 ust. 1 ustawy o VAT stanowi, że w zakresie, w jakim towary i usługi są wykorzystywane do wykonywania czynności opodatkowanych, podatnikowi przysługuje prawo do obniżenia kwoty podatku należnego o kwotę podatku naliczonego. Ponadto w art. 88 ust. 4 ww. ustawy znajdujemy zapis, iż prawo do odliczenia podatku VAT mają te podmioty, które zostały zarejestrowane jako czynni podatnicy VAT.

Te generalne zasady powodują niejednokrotnie duże trudności interpretacyjne (zwłaszcza w kontekście ,wagi” i roli rejestracji dla potrzeb podatku VAT). Określenie faktycznego prawo do skorzystania z prawa do podatku naliczonego przez podmioty niezarejestrowane (jak również ich kontrahentów), wymaga bowiem sięgnięcia nie tylko do ustaw, ale również do orzecznictwa krajowego i unijnego

Celem artykułu jest przedstawienie w ujęciu kompleksowym, zarówno w kontekście ustawodawstwa i orzecznictwa unijnego jak i krajowego, a także praktyki organów podatkowych, zagadnienia związku rejestracji dla potrzeb podatku VAT z fundamentalnym prawem podatnika tego podatku, tj. prawem do obniżenia kwoty podatku należnego o wartość podatku naliczonego.

Omawiając prawo kontrahenta podmiotu niezarejestrowanego do odliczenia podatku VAT przeanalizowano pojęcia „,dobrej wiary” i „należytej staranności”, zwłaszcza że ich dochowanie jest kluczowe w kontekście zachowania prawa do obniżenia podatku należnego o kwotę podatku naliczonego w sytuacjach podejrzeń o uczestnictwo w próbach wyłudzenia podatku VAT

Zagadnienie poruszone $\mathrm{w}$ artykule jest również nieodłącznie związane $\mathrm{z}$ neutralnością podatku VAT zawartą w dyrektywie 2006/112/WE Rady z dnia 28 listopada 2006 r. W sprawie wspólnego systemu podatku od wartości dodanej ${ }^{3}$, rozumianą jako stosowanie podatku od towarów i usług na wszystkich etapach obrotu gospodarczego z równoczesnym prawem do potrącenia podatku zawartego w poprzedniej fazie obrotu.

\section{REJESTRACJA}

\subsection{Definicja podatnika VAT}

Ogólna definicja podatnika VAT zawarta jest w art. 15 ustawy o VAT. Zgodnie z nim podatnikami są osoby prawne, jednostki organizacyjne niemające osobowości prawnej oraz osoby fizyczne, wykonujące samodzielnie działalność gospodarczą, bez względu na cel lub rezultat takiej działalności. Działalność gospodarcza obejmuje wszelką działalność producentów, handlowców lub usługodawców, w tym podmiotów pozyskujących zasoby naturalne oraz rolników, a także działalność osób wykonujących wolne zawody. Działalność gospodarcza obejmuje w szczególności czynności polegające na wykorzystywaniu towarów lub wartości niematerialnych i prawnych w sposób ciągły dla celów zarobkowych. Jest to ogólna definicja której uszczegółowienie i rozszerzenie (m.in. o podmioty dokonujące wewnątrzwspólnotowych dostaw nowych środków transportu, zobowiązane do uiszczenia cła itp.) zawarta jest w art.17 ustawy. Ponadto analizując pojęcie działalności gospodarczej

\footnotetext{
2 Tekst jedn. Dz.U. z 2017 r., poz. 1221 ze zm. (dalej jako ustawa o VAT).
}

${ }^{3}$ Dz.U. UE. L nr 347 ze zm. 
trudno pominąc jej definicję zawartą w ustawie z dnia 6 marca 2018 r. Prawo przedsiębiorców ${ }^{4}$ wchodzącej w skład tzw. Konstytucji dla biznesu. Art. 3 tej ustawy stanowi, że działalnością gospodarczą jest zorganizowana działalność zarobkowa, wykonywana we własnym imieniu i w sposób ciągły.

Zasadniczo przyjmuje się, że prowadzenia działalności gospodarczej w sposób ciągły, odpłatny i stały nadaje podmiotowi status podatnika VAT. A więc sporadyczne, czy okazjonalne podejmowanie czynności (nawet odpłatnej) nie powoduje jeszcze nadania takiego statusu.

Uznanie statusu podmiotu jako podatnika VAT stanowi niejednokrotnie powód dużych rozbieżności interpretacyjnych (tym większych, im bardziej złożona jest działalność podmiotu). Zauważyć jednakże należy, iż ze względu na podmiotowe zwolnienie z podatku określone w art. 113 ustawy o VAT (aktualnie do przekroczenia obrotu wynoszącego 200 tys. zł) nie powodują one aż tylu konfliktów co dawniej na linii podatnik - organ podatkowy.

\subsection{Termin i tryb rejestracji}

Termin dokonania rejestracji dla potrzeb podatku VAT określony został w art. 96 ust. 1 ustawy o VAT. Stanowi on, że podatnicy zobowiązani do rejestracji winni zgłosić się do niej najpóźniej przed dniem wykonania pierwszej czynności. W tym terminie więc podatnik ma obowiązek złożyć do organu podatkowego zgłoszenie VAT-R. W ustawie o VAT brak jest przepisów określających termin oczekiwania na rejestrację. Znajdujemy zapis (art. 96 ust. 4 ustawy o VAT) który mówi, że naczelnik urzędu skarbowego rejestruje podatnika jako podatnika VAT czynnego ,po weryfikacji danych zawartych w zgłoszeniu rejestracyjnym". Taki charakter zapisu powoduje, że do szybkości przebiegu procesu rejestracji potrzebna jest współpraca przedsiębiorcy z organem podatkowym. Im przebiega ona lepiej tym czas oczekiwania na rejestrację jest krótszy. Zauważyć przy tym należy, że zgłoszenie rejestracyjne winno być rzetelne, a podane w nim dane zgodne z rzeczywistością. Ustawodawca przewidział sytuacje $w$ których organ podatkowy może poddać w wątpliwość dane zawarte w zgłoszeniu rejestracyjnym. Enumeratywnie powody takie są wymienione w art. 96 ust.4a ustawy o VAT. Do powodów tych należą m.in. podanie danych niezgodnych z rzeczywistością (podmiot nie istnieje, lub posługuje się fikcyjnymi danymi) lub brak kontaktu z podatnikiem.

Po pozytywnej weryfikacji danych zawartych w zgłoszeniu VAT-R naczelnik urzędu skarbowego rejestruje podatnika jako podatnika VAT czynnego bądź zwolnionego. Istnieje możliwość potwierdzenia tego faktu - odbywa się to wyłącznie na wniosek podatnika na formularzu VAT-5.

\subsection{Aktualizacja danych $w$ rejestrze}

Jeżeli dane zawarte w zgłoszeniu rejestracyjnym ulegną zmianie, to podatnik obowiązany jest zgłosić zmianę do naczelnika urzędu skarbowego w terminie 7 dni, licząc od dnia, w którym nastąpiła zmiana (art. 96 ust. 12 ustawy o VAT). Co do zasady obowiązek ten nie dotyczy podatników, którzy dokonują wyłącznie zmian objętych wpisem do Centralnej Ewidencji Działalności i Informacji Gospodarczej. Zmiany takie dokonywane są na formularzu CEIDG-1 i nie ma obowiązku ,powielać” ich na formularzu VAT-R. Niejednokrotnie

\footnotetext{
${ }^{4}$ Tekst jedn. Dz.U. z 2018 r., poz. 646.
} 
istnieje jednak konieczność zaktualizowania VAT-R. Dzieje się tak np. w przypadku zmiany sposobu rozliczania podatku (np. przejście z okresu kwartalnego na miesięczny, bądź odwrotnie). Ponadto zawsze istnieje obowiązek złożenia formularza VAT-R jeśli dokonywana zmiana powoduje zmianę właściwości organu podatkowego.

\subsection{Wykreślanie $\mathrm{z}$ rejestru podatników}

Jeżeli podatnik zarejestrowany jako podatnik VAT zaprzestał wykonywania czynności podlegającej opodatkowaniu, jest on obowiązany zgłosić ten fakt naczelnikowi urzędu skarbowego (art. 96 ust. 6 ustawy o VAT). Zgłoszenie to dokonywane jest na formularzu VAT-Z i stanowi podstawę do wykreślenia podatnika z rejestru jako podatnika VAT. Jest to generalna zasada stosowana w sytuacjach, gdy podatnik wykazuje się starannością i rzetelnością w wykonywaniu obowiązków podatkowych. Jednakże ustawodawca przewidział, iż nie wszyscy podatnicy będą dochowywać takiej staranności. W ust. 9 wspomnianego artykułu zawarto regulacje dotyczące wykreślania podatnika z rejestru jako podatnika VAT (i to bez zawiadamiania go o tym fakcie) w sytuacjach, gdy brak jest kontaktu z podatnikiem (pomimo udokumentowanych prób), podatnik nie istnieje lub dane w zgłoszeniu rejestracyjnym okażą się niezgodne z prawdą. Zauważyć należy, że powody wykreślenia z rejestru podatników VAT czynnych są tożsame z powodami stanowiącymi powód do odmowy rejestracji. Będą one w zdecydowanej większości dotyczyć jednak podatników funkcjonujących od dłuższego czasu i zarejestrowanych przed nowelizacją ustawy o VAT utrudniającą czy wręcz uniemożliwiającą ich zarejestrowanie.

W ust. 9a art. 96 wymieniono inne powody wykreślania podatnika z rejestru VAT. Należą do nich m.in. zawieszenie działalności gospodarczej, składanie deklaracji w których nie wykazano dostaw i nabyć czy brak deklaracji. Analogicznie, gdy podmiot wystawił faktury dokumentujące czynności które nie zostały wykonane, bądź wiedział (lub miał uzasadnione podstawy by wiedzieć), iż uczestniczy w „karuzeli podatkowej”. “ $Z$ uwagi na to, że ust. 9a nie stanowi expressis verbis jak ust. 9, że wykreślenie następuje z urzędu bez konieczności zawiadamiania o tym podatnika, należałoby uznać, że w tych sytuacjach, o których mowa w ust. 9, podatnik o takim wykreśleniu powinien być zawiadamiany"5.

W kolejnych ustępach art.96 ustawodawca wymienił warunki i zastrzeżenia, kiedy wykreślenia nie mają miejsca (pomimo spełnienia ww. warunków), a także, na jakich warunkach może nastąpić przywrócenie podatnika jako podatnika VAT czynnego.

\section{REJESTRACJA A PRAWO DO ODLICZENIA PODATKU NALICZONEGO}

\subsection{Ustawodawstwo krajowe - ogólne zasady}

Prawo do odliczenia podatku zawartego w fakturach zakupowych jest podstawowym prawem podatnika w rozliczaniu podatku od towarów i usług. Ustawodawca podał ogólną zasadę warunkującą skorzystanie z tego prawa. Jest ona zawarta w art. 86 ust. 1 ustawy o VAT. Stanowi on, że w zakresie, w jakim towary i usługi są wykorzystywane do wykonywania czynności opodatkowanych podatnikowi przysługuje prawo do obniżenia kwoty podatku należnego o podatek naliczony. Jednocześnie w art. 88 ust. 4 zawarto zastrzeżenie,

\footnotetext{
5 J. Zubrzycki, Leksykon VAT, t. 1, Wrocław 2017, s. 1273.
} 
że obniżenie to lub zwrotu różnicy podatku należnego nie stosuje się do podatników, którzy nie są zarejestrowani jako podatnicy VAT czynni.

\subsection{Interpretacje podatkowe}

Temat rejestracji dla potrzeb podatku VAT w kontekście prawa do odliczenia podatku naliczonego był $i$ jest przedmiotem wielu interpretacji podatkowych. W interpretacjach tych w głównej mierze poruszane jest zagadnienie związane z ustaleniem momentu od którego podatnik ma prawo do obniżenia kwoty podatku należnego. Kwestią budzącą najwięcej sporów jest zagadnienie, czy faktury dokumentujące nabywane towary i usługi poczynione przed złożeniem zgłoszenia rejestracyjnego VAT-R stanowią podstawę do takiego obniżenia. Jedną z ostatnich interpretacji w tym zakresie jest interpretacja dyrektora Krajowej Informacji Skarbowej z dnia 9 maja 2018 r. ${ }^{6}$. W interpretacji tej zawarto stwierdzenie (które stanowi kwintesencję innych interpretacji podatkowych w ostatnim czasie $)^{7}$, że ,przepis ustawy o podatku od towarów i usług przewiduje sankcję w postaci pozbawienia podatnika prawa do obniżenia kwoty lub zwrotu różnicy podatku należnego w razie niezarejestrowania się, ale nie wskazuje wprost, z jakim momentem - z punktu widzenia niemożności odliczenia podatku naliczonego - należy wiązać status podatnika (zarejestrowany czy nie). $\mathrm{Z}$ art. 88 ust. 4 ww. ustawy nie wynika bowiem, aby do nabycia uprawnienia do obniżenia kwoty podatku należnego o kwotę podatku naliczonego koniecznym było posiadanie statusu podatnika VAT czynnego w momencie otrzymania faktury. Podatnik nabywa więc prawo do odliczenia podatku naliczonego w momencie otrzymania faktury, lecz aby uprawnienie to zrealizować musi posiadać status podatnika VAT czynnego”. I dalej: „Stwierdzić należy zatem, że ustawa nie pozbawia podatnika prawa do dokonania odliczenia podatku od zakupów dokonanych przed rejestracją, o ile zakupione towary i usługi będą wykorzystywane do bieżącej lub przyszłej działalności opodatkowanej (oraz ewentualnie spełniać inne warunki określone w przepisach powołanej ustawy). Niemniej ustawodawca narzucił podatnikom, chcącym dokonać odliczenia podatku VAT od poczynionych nabyć, obowiązek rejestracji jako podatnik VAT czynny". Organ dokonujący interpretacji wyraźnie wskazał, iż to na dzień konsumpcji prawa do podatku naliczonego podatnik winien posiadać status podatnika VAT czynnego, a nie na dzień dokonywania nabyć. Stwierdzono to w dalszej części interpretacji: „Należy rozróżnić moment powstania prawa do odliczenia od momentu skorzystania z tego prawa. Jego realizacja następuje poprzez złożenie deklaracji podatkowej, wyrażającej wolę skorzystania przez podatnika z prawa do odliczenia i aby skutecznie zrealizować już powstałe uprawnienie, podatnik musi usunąć - najpóźniej przed skorzystaniem z tego prawa - wszelkie przesłanki negatywne, w tym brak rejestracji, który uniemożliwia identyfikowanie go jako podatnika".

\subsection{Orzeczenia polskich sądów administracyjnych}

Analizując orzeczenia polskich sądów administracyjnych w zakresie objętym artykułem zauważyć należy dużą zbieżność pomiędzy interpretacjami podatkowymi a tym orzecznic-

\footnotetext{
${ }^{6}$ Interpretacja indywidualna dyrektora Krajowej Informacji Skarbowej z dnia 9 maja 2018 r., nr 0114-KDIP1-3.4012.197.2018.1.

${ }^{7}$ Por.: interpretacje indywidualne dyrektora Krajowej Informacji Skarbowej z dnia 10 lipca 2017 r., nr_0114-KDIP1-3.4012.157.2017.3.ISK czy z dnia 27 września 2017 r., nr 0114-KDIP1$-1.4012 .366 .2017 .1 . J O$.
} 
twem. Biorąc pod uwagę powyższe i fakt, że organy podatkowe nie kwestionują prawa do odliczenia podatku naliczonego sprzed rejestracji aktualnie wojewódzkie sądy administracyjne i w ślad za tym Naczelny Sąd Administracyjny stosunkowo rzadko zajmują się tą tematyką. Analizując jednak tę kwestię trudno pominąć wyrok Naczelnego Sądu Administracyjnego z dnia 9 lipca 2010 r. ${ }^{8}$. NSA w przedmiotowym orzeczeniu poruszył m.in. kwestię, czy podatnikowi, który nie dokonał zgłoszenia rejestracyjnego przysługuje prawo do odliczenia podatku naliczonego (w tej akurat sprawie w decyzji wydanej przez organ podatkowy). NSA w konkluzji stwierdził, iż ,sprzeczne z zasadą neutralności i proporcjonalności jest pozbawienie podatnika na podstawie art. 88 ust. 4 ustawy o VAT, uwzględnienia $\mathrm{w}$ rozliczeniu podatkowym podatku naliczonego w sytuacji, gdy podatnik błędnie przeświadczony, że korzysta ze zwolnienia z podatku od towarów i usług na podstawie art. 113 ust. 1 ustawy o VAT, mimo ciążącego na nim obowiązku nie dokonał zgłoszenia rejestracyjnego, o którym mowa w art. 96 ustawy o VAT. W sytuacji, gdy rozliczenia należnego zobowiązania w podatku od towarów i usług dokonuje organ podatkowy w drodze decyzji, jest on zobowiązany uwzględnić podatek naliczony wynikający z okazanych przez podatnika faktur uprawniających do pomniejszenia podatku należnego"».

\subsection{Orzeczenia Trybunału Sprawiedliwości}

Trybunał Sprawiedliwości w wyroku z dnia 9 lipca 2015 r. w sprawie C-183/14 ${ }^{10}$ Radu Florin Salomie, Nicolae Vasile Oltean przeciwko Direcția Generală a Finanțelor Publice Cluj, potwierdził wcześniejszą linię orzeczniczą zawartą min. w wyrokach C-268/83, C-110/94, C-400/98 czy C-385/09 ${ }^{11}$. W sentencji wyroku Trybunał Sprawiedliwości orzekł: „Dyrektywa Rady 2006/112/WE z dnia 28 listopada 2006 r. w sprawie wspólnego systemu podatku od wartości dodanej sprzeciwia się, w okolicznościach takich jak w postępowaniu głównym, przepisom krajowym, na mocy których prawa do odliczenia naliczonego podatku od wartości dodanej należnego lub zapłaconego od towarów lub usług wykorzystanych do celów transakcji podlegających opodatkowaniu odmówiono podatnikowi mającemu jednak zapłacić podatek, który powinien był on pobrać, wyłącznie z tego względu, że nie był on zarejestrowany do celów podatku od wartości dodanej przy dokonywaniu tych transakcji, i to do czasu gdy nie został on prawidłowo zarejestrowany do celów podatku od wartości dodanej i nie została złożona deklaracja w zakresie należnego podatku”.

8 Wyrok NSA z dnia 9 lipca 2010 r., I FSK 1132/09, CBOSA.

9 Por. wyrok WSA w Warszawie z dnia 30 kwietnia 2015 r., III Sa/Wa 2327/14, CBOSA.

10 Wyrok TS z dnia 9 lipca 2015 r. w sprawie C-183/14 Radu Florin Salomie, Nicolae Vasile Oltean przeciwko Direcția Generală a Finanțelor Publice Cluj, CURIA.

11 Por. wyrok TS z dnia 14 lutego 1985 r. w sprawie C-268/83 Rompelman przeciwko Minister van Financien; wyrok TS z dnia 29 lutego 1996 r. w sprawie C-110/94 Inzo przeciwko Belgische Staat; wyrok TS z dnia 8 czerwca 2000 r. w sprawie C-400/98 Brigitte Breitsohl przeciwko Finanzamt Goslar; wyrok TS z dnia 21 października 2010 r. w sprawie C-385/09 Nidera Handelscompagnie BV przeciwko Valstybinë mokesčiř inspekcija prie Lietuvos Respublikos finanšr ministerijos, CURIA. 


\section{REJESTRACJA KONTRAHENTA, A PRAWO DO PODATKU NALICZONEGO}

\subsection{Pojęcie dobrej wiary i należytej staranności}

Pojęcie dochowania należytej staranności jest kluczowym w kontekście zachowania prawa do obniżenia podatku należnego o kwotę podatku naliczonego w sytuacjach podejrzeń o uczestnictwo w tzw. karuzelach podatkowych czy próbach wyłudzenia podatku VAT. Jednocześnie klauzula ta ma fundamentalne znaczenie w sytuacji odliczenia podatku VAT z faktury wystawionej przez kontrahenta nieposiadającego statusu podatnika VAT czynnego.

W ustawodawstwie krajowym (w tym w ustawach i rozporządzeniach dotyczących podatku VAT) nie zawarto definicji należytej staranności. Nie zawarto w nich również definicji dobrej wiary, która z poprzednim pojęciem jest nierozerwalnie związana.

Dobra wiara to jedno z najważniejszych pojęć kodeksu cywilnego ${ }^{12}$. Jest jedną $\mathrm{z}$ tzw. klauzul generalnych prawa cywilnego. Jest również klauzulą ochronną - przyjmuje się, że strona działa w dobrej wierze, natomiast działanie w złej trzeba dowieść.

„Przyjmuje się, że przez pojęcie dobrej wiary należy rozumieć stan psychiczny pewnej osoby polegający na jej błędnym, ale usprawiedliwionym w świetle współistniejących okoliczności przekonaniu, że prawo jej przysługuje czy też określony stosunek prawny istnieje"13.

Analizując pojęcie należytej staranności znów należy odwołać się do ustawy kodeks cywilny. Art. $355 \S 1$ stanowi, iż dłużnik obowiązany jest do staranności ogólnie wymaganej w stosunkach danego rodzaju (należyta staranność). Ponadto w $§ 2$ czytamy, że należytą staranność dłużnika w zakresie prowadzonej przez niego działalności gospodarczej określa się przy uwzględnieniu zawodowego charakteru tej działalności. „Kwestię staranności rozpatrujemy każdorazowo w płaszczyźnie stosunków danego rodzaju"14.

\subsection{Praktyka organów podatkowych}

Analizując praktykę organów podatkowych oraz stanowisko Ministerstwa Finansów zauważyć należy duży nacisk kładziony na scharakteryzowane powyżej zagadnienia dobrej wiary i należytej staranności.

Kwestią niewątpliwie sporną jest, czy zakup od podatnika nieposiadającego statusu podatnika VAT czynnego, a następnie odliczenie podatku zawartego w wystawionej przez niego fakturze jest naruszeniem zasady należytej staranności.

$\mathrm{Na}$ brak definicji w prawie podatkowym ww. zagadnień i problemy z tym związane zwrócił min. uwagę poseł Jakub Kulesza w interpelacji poselskiej nr 11813 z dnia 06.04.2017 r. ${ }^{15}$ skierowanej do ministra finansów. W odpowiedzi na interpelację i oczekiwania podatników Ministerstwo Finansów rozpoczęło konsultacje w zakresie „listy przesłanek należytej staranności po stronie nabywcy w transakcjach krajowych w kontekście

\footnotetext{
${ }^{12}$ Ustawa z dnia 23 kwietnia 1964 r. Kodeks cywilny (tekst jedn. Dz.U. z 2017 r., poz. 459 ze zm.).

${ }^{13}$ S. Kalus, Komentarz do art. 7 Kodeksu cywilnego [w:] Kodeks cywilny. Komentarz, t. 1, red. M. Fras, M. Habdas, WKP, 2018.

14 T. Wiśniewski, Komentarz do art.355 kodeksu cywilnego [w:] Kodeks cywilny. Komentarz, red. G. Bieniek, t. 3, WKP, 2011.

15 http://www.sejm.gov.pl/Sejm8.nsf/InterpelacjaTresc.xsp?key=09FD2CC4 (dostęp: 22.06.2018 r.).
} 
prawa do odliczenia podatku naliczonego". Owocem tych konsultacji było powstanie dokumentu pod nazwą „Metodyka dochowania należytej staranności przez nabywców towarów w transakcjach krajowych"16.

Już we wstępie do przedmiotowego dokumentu MF oceniło, iż na początku współpracy z nowym kontrahentem podatnik winien dokonać sprawdzenia kontrahenta pod względem formalnym, a przede wszystkim czy jest on zarejestrowanym podatnikiem VAT. Jednocześnie w dokumencie tym MF stwierdziło, że „,na brak dochowania przez podatnika należytej staranności mogą wskazywać następujące okoliczności: podatnik nie weryfikował w sposób regularny, czy kontrahent jest zarejestrowany jako podatnik VAT czynny".

Zgodzić się należy, że aktualnie sprawdzenie statusu podatnika nie wymaga już wizyty w urzędzie skarbowym i nie jest czynnością skomplikowaną. Nabywca może taki fakt zweryfikować poprzez usługę „Sprawdzenie statusu podmiotu VAT” dostępną na Portalu Podatkowym.

Niewątpliwie jednak sporną kwestią pozostaje, czy brak takowego sprawdzenia jest sam w sobie naruszeniem zasady dochowania należytej staranności.

\subsection{Orzeczenia polskich sądów administracyjnych}

Kwestia możliwości odliczania podatku naliczonego z faktury wystawionej przez kontrahenta nieposiadającego statusu VAT czynnego niejednokrotnie była przedmiotem rozważań tak wojewódzkich sądów administracyjnych, jak i NSA. Niewątpliwie bardzo ciekawym wyrokiem NSA, który badał tę kwestię, jest wyrok z dnia 7 marca 2018 r. I FSK $769 / 16^{17}$. W przedmiotowym orzeczeniu NSA stwierdził (opierając się na orzecznictwie Trybunału Sprawiedliwości), iż „warunki formalne nie mogą stać na przeszkodzie realizacji prawa do odliczenia. Trybunał wielokrotnie bowiem podkreślał, że ewentualne uchybienie przez dostawcę towarów obowiązkowi zgłoszenia rozpoczęcia działalności podlegającej opodatkowaniu nie może podważać prawa do odliczenia podatku przysługującego odbiorcy dostarczonych towarów w zakresie naliczonego podatku VAT. W związku z tym rzeczonemu odbiorcy przysługuje prawo do odliczenia, nawet jeżeli dostawca jest podatnikiem, który nie został zarejestrowany dla celów podatku VAT”. I dalej: „Jeżeli podmiot gospodarczy podjął wszelkie działania, jakich można od niego w sposób uzasadniony oczekiwać, w celu upewnienia się, że transakcje w których uczestniczy nie wiążą się z przestępstwem, czy to w zakresie podatku VAT czy w innej dziedzinie, może on domniemywać legalność tych transakcji bez ryzyka utraty prawa do odliczenia naliczonego podatku VAT" ${ }^{18}$.

Jednakże w wyroku tym NSA jednocześnie pokusił się o wyznaczenie granicy czasowej domniemania dobrej wiary. Otóż w rozpatrywanym stanie faktycznym jednostka pozyskała na pewnym etapie współpracy z kontrahentem (wrzesień 2014 r.) informację, że kontrahent ten nie został zarejestrowany jako podatnik VAT czynny. NSA jednoznacznie stwierdził, iż moment pozyskania takiej informacji wyznacza granicę działania w dobrej wierze, albowiem zawierając dalsze transakcje z tym kontrahentem od momentu, w którym strona uzyskała informację o nierzetelności swojego kontrahenta ochrona podatnika, wynikająca z przedstawionego wyżej orzecznictwa TS, przestała obowiązywać. „O ile zatem można było zakładać dobrą wiarę podatnika do września 2014 r., to faktury VAT wystawione przez

\footnotetext{
${ }^{16} \mathrm{https}: / /$ www.mf.gov.pl/c/document_library/get_file?uuid=2eba55c3-cba9-4f1d-aa36684f76b2d561\&groupId=764034 (dostęp: 23.06 .2018 r.).

17 Wyrok NSA z dnia 7 marca 2018 r. I FSK 769/16, CBOSA.

${ }^{18}$ Ibidem.
} 
kontrahenta skarżącej Spółki po tej dacie, nie powinny już stanowić podstawy do odliczenia podatku naliczonego z nich wynikającego" 19 .

\subsection{Orzeczenia Trybunału Sprawiedliwości}

Sprawa odliczania podatku naliczonego zawartego w fakturach zakupowych wystawionych przez podmiot niezarejestrowany była częstym przedmiotem rozważań Trybunału Sprawiedliwości ${ }^{20}$. W wyroku C-101/16 z dnia 17 października 2017 r. ws. Paper Consult SRL przeciwko Direcția Regională a Finanțelor Publice Cluj-Napoca, Administrația Județeană a Finanțelor Publice Bistrița-Năsăud ${ }^{21}$ Trybunał Sprawiedliwości potwierdził linię orzeczniczą, którą prezentuje niezmiennie od wielu już lat.

Sprawa dotyczyła następującego stanu faktycznego i prawnego: Spółka Rom Packaging świadczyła usługi na rzecz spółki Paper Consult. Jednocześnie Firma Rom Packaging została wykreślona z rejestru podatników VAT. W związku z tym organy podatkowe uznały, że spółka Paper Consult nie mogła odliczyć tego podatku wynikającego z faktur wystawionych przez spółkę Rom Packaging.

W sentencji wyroku Trybunał zawarł stwierdzenie, że „,W sprawie w postępowaniu głównym, na mocy którego podatnikowi odmawia się prawa do odliczenia podatku od wartości dodanej z tego względu, że podmiot, który świadczył na jego rzecz usługę i wystawił z tego tytułu fakturę, na której wyraźnie zostały wskazane wydatki i podatek od wartości dodanej, został uznany przez organ podatkowy państwa członkowskiego za nieaktywny, przy czym to uznanie za nieaktywnego zostało opublikowane i jest dostępne na stronie internetowej dla wszystkich podatników w tym państwie, jeżeli owa odmowa prawa do odliczenia jest systematyczna i ostateczna oraz nie pozwala na przedłożenie dowodów na niepopełnienie przestępstwa podatkowego lub na brak utraty wpływów podatkowych"22. Jak wynika z sentencji postanowienia - brak zarejestrowania podatnika jako podatnika VAT czynnego nie może stanowić sam w sobie wystarczającej przesłanki do kwestionowania przez organy podatkowe prawa do odliczenia podatku naliczonego.

\section{PODSUMOWANIE}

Wobec faktu, iż ustawodawstwo krajowe jedynie bardzo ogólnie odnosi się do pojęcia rejestracji dla potrzeb VAT w kontekście prawa do odliczenia podatku naliczonego stanowi to przesłankę do stosowania szeroko pojętych interpretacji zarówno przez organy podatkowe, jak i sądownictwo krajowe i unijne.

Orzeczenia TS i opierające się na nich w swojej linii orzeczniczej sądownictwo krajowe jednoznacznie akcentuje potrzebę rozdzielenia przypadków w zależności od ich stanu faktycznego, a w szczególności zamiaru podatnika. Z orzecznictwa tego można wywieść, że podstawą do pozbawienia podatnika prawa do odliczenia podatku naliczonego nie mogą

19 Ibidem.

${ }^{20}$ Por.: wyrok TS z dnia 22 października 2015 r., w sprawie C-277/14 PPUH Stehcemp sp.j. Florian Stefanek, Janina Stefanek, Jarosław Stefanek przeciwko dyrektorowi Izby Skarbowej w Łodzi, CURIA.

21 Wyrok TS z dnia 17 października 2017 r. ws. C-101/16 Paper Consult SRL przeciwko Direcția Regională a Finanțelor Publice Cluj-Napoca, Administrația Județeană a Finanțelor Publice Bistrița-Năsăud, CURIA.

22 Ibidem. 
być jedynie tzw. błędy formalne - a to do nich zaliczyć można brak rejestracji dla potrzeb podatku VAT. Inaczej przedstawia się sytuacja w przypadku celowego uczestnictwa podatnika w wyłudzeniach podatku VAT (a niejednokrotnie brak rejestracji jest jednym z symptomów działania mającego na celu wyłudzenia podatku). Zgodnie z orzecznictwem TS i sądów krajowych przypadki takie powinny być ścigane zarówno przez wymiar sprawiedliwości, jak również karane podatkowo (w tym poprzez pozbawianie prawa do obniżenia podatku należnego o podatek naliczony).

Reasumując: prawo do odliczenia podatku naliczonego jako nieodłącznie związane z neutralnością podatku VAT zawartą w dyrektywie 2006/112/WE Rady z dnia 28 listopada 2006 r. w sprawie wspólnego systemu podatku od wartości dodanej, może zostać zakwestionowane jedynie w ściśle określonych okolicznościach których udowodnienie stanowi obowiązek organu podatkowego.

\section{LITERATURA}

1. Zubrzycki J., Leksykon VAT, t. I, Wrocław 2017.

\section{PRAWODAWSTWO}

1. Dyrektywa 112/2016/WE RADY z dnia 28 listopada 2006 r. w sprawie wspólnego systemu podatku od wartości dodanej (Dz.U. L 347 z 11.12.2006 r., s. 1).

2. Ustawa z dnia 11 marca 2014 r. o podatku od towarów i usług (tekst jedn. Dz.U. z 2017 r., poz. 1221 ze zm.).

3. Ustawa z dnia 23 kwietnia 1964 r. Kodeks cywilny (tekst jedn. Dz.U. z 2017 r., poz. 459 ze zm.).

\section{NETOGRAFIA}

1. Centralna Baza Orzeczeń Sądów Administracyjnych, http://orzeczenia.nsa.gov.pl (dostęp: 20.06.2018 r.).

2. InfoCuria - Orzecznictwo Trybunału Sprawiedliwości, http://curia.europa.eu/juris/ liste.jsf (dostęp: 21.06.2018 r.).

3. Kalaus S., Komentarz do art. 7 Kodeksu cywilnego [w:] Kodeks cywilny. Komentarz, t. I, red. M. Fras, M. Habdas, WKP, 2018, https://borg.wolterskluwer.pl/Products/ Index.ashx (dostęp: 18.06.2018 r.).

4. Wiśniewski T., Komentarz do art. 355 kodeksu cywilnego [w:] Kodeks cywilny. Komentarz, t. III, red. G. Bieniek, LexisNexis, 2011, https://borg.wolterskluwer.pl/ Products/Index.ashx (dostęp: 19.06.2018 r.).

5. www.sejm.gov.pl (dostęp: 19.06.2018 r.).

\section{STATUS OF AN ACTIVE VAT ENTIRER AND THE RIGHT TO DEDUCT THE RENEWED TAX}

The article presents an issue that still causes many disputes between the tax authorities and the taxpayer, and therefore the right to deduct input tax in the absence of registration for VAT 
purposes. The article characterizes the definition of active VAT taxpayer included in the VAT Act. In addition, the deadlines and mode of registration as well as the updating of data contained in the VAT register are discussed. The issue of deletions from the register of active VAT taxpayers divided into reasons for deletion was also discussed. The issue which is the topic of the article has been presented in two ways. One of the chapters was devoted to the analysis of the situation of an entity that purchases goods or services documented with VAT invoices, without being a registered active VAT payer, and the next one discusses these issues from the counterparties of an unregistered entity. Analyzing the situation of contractors purchasing goods and services from an unregistered entity, particular attention was paid to the issues of "good faith" and "due diligence" inherent in the right to deduct VAT in such a situation. This issue was presented in the context of national legislation (in particular the VAT Act), the practices of tax authorities and the positions of the Ministry of Finance (including tax interpretations), as well as the case law of the Court of Justice and national courts. The basic conclusion resulting from the article is the need for the tax authorities and the judiciary to examine the good faith of the taxpayer, and to comply with the principles of due diligence. In summary - it boils down to the question whether the taxpayer in a specific case acted in a fair and honest way. If so - it is legitimate to grant him the right to deduct input tax, even with certain procedural or procedural irregularities (including lack of registration for VAT purposes).

Keywords: VAT, VAT registration, Court of Justice, national judicature, tax authorities, input tax.

DOI: $10.7862 /$ rz.2018.mmr.35

Tekst złożono do redakcji: czerwiec 2018 r.

Tekst przyjęto do druku: wrzesień $2018 \mathrm{r}$. 
